\title{
MENGUJI NETRALITAS ILMU PENGETAHUAN
}

\author{
Syaiful Bakri \\ Sekolah Tinggi Ilmu Syariah Darul Falah Bondowoso \\ Email : syaifulbakridafa@gmail.com
}

\begin{abstract}
Abstrak
Dalam tulisan ini membahas secara menditail tentang ilmu pengetahuan sebagai satusatunya senjata peradaban kehidupan. Dalam perkembangannya, ilmu pengetahuan mengalami kegamangan status. Dalam kegamangannya tersebut, sebagai ilmu yang berdiri sendiri dituntut untuk mampu tunduk pada aturan-aturannya. Berbekal ilmu pengetahuan, manusia mampu, menciptakan peradaban dan dengan ilmu pengetahuan pula manusia dapat menciptakan malapetaka dalam lembar kehidupannya. Sehingga, peran netral dan tidak netralnya ilmu dalam kehidupan manusia menjadi tanda tanya besar.
\end{abstract}

Kata kunci : Ilmu, netral, netralitas, nilai, bebas nilai

\section{Pendahuluan}

Pengetahuan yang merupakan produk kegiatan berpikir merupakan obor dan penguat peradaban dimana manusia menemukan dirinya dan menghayati hidup dengan lebih sempurna. Berbagai peralatan dikembangkan manusia untuk meningkatkan kualitas hidupnya dengan jalan menerapkan pengetahuan yang di perolehnya pada sendi-sendi kehidupan.

Namun dalam kenyataanya, apakah ilmu merupakan suatu berkah yang selalu berpihak pada kesejahteraan manusia? sementara kita tahu, pada terakhir ini ilmu sangat mempengaruhi reproduksi atau penciptaan manusia itu sendiri. Ilmu dengan sendirinya telah menimbulkan gejala dehumanisasi. Ilmu pengetahuan menghadirkan memungkinkan dan telah mampu mengubah hakikat manusia itu sendiri. Ilmu pengetahuan bukan lagi sebagai sarana mencapai tujuan hidup, namun ilmu adalah menciptakan tujuan hidup itu sendiri. Tanpa kita sadari kemegahan ilmu justru memperalat manusia itu sendiri. 
Eistein pernah berpesan pada mahasiswanya California institute of technology, "mengapa ilmu sangat indah ini, yang menghemat kerja dan membuat hidup lebih mudah, hanya membawa kebahagiaan yang sedikit kepada kita ?. dalam peperangan, ilmu menyebabkan kita saling meracun dan menjegal. Dalam perdamaian, dia membuat hidup kita dikejar waktu dan penuh ketidaktentuan."

Berangkat dari asumsi dasar tersebut, muncul pertannyaan yang menggelitik bagi penulis, lalu dimanakah posisi ilmu pengetahuan dan bagaimana sikap yang semestinya dikembangkan para ilmuwan dalam menyikapi posisi ilmu tersebut.untuk menemukan jawaban dari permasalahan ini, baiknya penulis mencoba memaparkan terlebih dahulu apa itu ilmu pengetahuan dan tiga titik tumpu landasan ilmu itu sendiri.

\section{TA'RIF ILMU , NILAI DAN NETRAL}

Kata ilmu berasa dari Bahasa Arab ('alima) yang berarti pengetahuan.pemakaian ilmu dalam Bahasa Indonesia diekuivalenkan dengan istilah science. Sementara kata science sendiri berasal dari Bahasa latin yaitu : scio, scire, yang juga berarti pengetahuan. Pada dasarnya ilmu merupakan kelanjutan konseptual dari ciri "ingin tahu" (curiocity) sebagai kodrat manusia.

Nilai berasal dari kata value yang berarti ilmu simbol yang didasarkan pada hubungan dengan simbol-simbol yang lain dalam satu sistem Bahasa. Adakalanya nilai berarti harga, sifat-sifat atau hal-hal yang penting dan berguna bagi kemanusiaan.

Sesuatu dikatakan mempunyai nilai apabila ia bermanfaat dalam kaca mata manusia yang memberikan penilaiaannya. Sehingga nilai bisa berarti kualitas dari sesuatu. Jika dikatakan lukisan itu indah maka yang dimaksud dengan nilai "indah" adalah kualitas estetika dari lukisan tersebut, bukan benda lukisannya. Ukuran dari kualitas itu adalah bermanfaat atau tidak bagi kepentingan manusia, baik kepentingan itu bersifat lahiriyah atau batiniyah. Karena berkaitan dengan kepentingan manusia, maka nilai merupakan kualitas yang selalu ingin diwujudkan. Nilai tidak untuk disimpan sebagai kekayaan batiniyah saja.

Adapun pengertian "netral" adalah tidak berpihak, tidak ikut, tidak membantu salah satu pihak, tidak berwarna yang artinya dapat dipadukan dengan segala warna, bebas yang berarti tidak terikat pada apapupun. Istilah "menetralkan" sebagai bentuk kata kerja dari 
netral berarti menjadikan sesuatu untuk tidak berpihak. Sedangkan "netralitas" berarti suatu keadaan dan sikap netral yang tidak memihak (bebas).

Semua pengetahuan apakah itu ilmu, seni atau pengetahuan apa saja pada dasarnya bertumpu pada tiga landasan, yaitu ontologis, epistemologis dan aksiologis. Yang membedakan diantaranya adalah sejauh mana landasan-landasan ketiga aspek ini diperkembangkan dan dilaksanakan.

Secara ontologis, ilmu mengajarkan cara berfikir yang cermat dan tidak kenal lelah (enigmatik), yaitu persoalan yang selalu berkembang secara terus menerus sehingga membutuhkan pemecahan secara kontinyu. Ilmu juga menuntut orisinalitas berfikir (context of discovery), yaitu lingkup penemuan yang didukung oleh curiosity (rasa ingin tahu), creativity (kreatifitas), dan heuristic (menemukan sesuatu yang baru/logika kreatif).

Atas dasar analisa di atas, tesis penulis menunjukkan bahwa pada dasarnya secara ontologis, netralitas ilmu yang bagi penulis identik dengan bebas nilai (free value)semata-mata human centris sebagaimana yang ditawarkan oleh kaum positivistik.

Masalah epistemologi bersangkutan dengan pertanyaan-pertanyaan tentang pengetahuan, yaitu bagaimana dan dengan sarana apakah kita dapat memperoleh pengetahuan. Sedangkan cara untuk memperoleh ilmu adalah melalui pengalaman, rasional, fenomenal, intuisif, metode ilmiah. Sejauh pengamatan penulis dari segi pengalaman, suatu pengalaman ternyata mempunyai nilai subyektif, jika kita tilik eksistensi ilmu selama ini cukup relevan dengan subyektifitas masing-masing disiplin keilmuannya. Sementara, jika kita tinjau dari rasionalitas keilmuan itu sendiri, ilmu yang selama ini berkembang dan kita geluti tidak dianggap valid apabila ilmu tidak memenuhi standar nalar atau rasional.

Dengan sarana tersebut di atas, kiranya jelas bagi kita bahwa kenetralan ilmu pengetahuan dengan segala aspek dan metodologinya tidak mempunyai kecenderungan pada satu demensi saja, melainkan ilmu menjadi sebuah kenetralan dalam merangkul berbagai jangkauan (theology absolut).

Dengan aksiologi, maka masalah yang muncul pada terma ini adalah mengenai tujuan utama dari ilmu. Berdasarkan perkembangan ilmu akhir-akhir ini, maka semakin di takjubkan dengan prestasi yang sangat brilian dari kualitas ilmu pengetahuan. Ilmu dalam perspektif sejarah kemanusiaan mempunyai puncak kecemerlangan masing- 
masing, namun sayangnya disatu sisi kecemerlangan ilmu pengetahaun membawa mala petaka bagi kehidupan ini.

Hadirnya unsur kimia sebagai salah satu penemuan obat-obatan dan unsur fisika-teori fisika nuklir dan fisika merupakan kemajuan yang sangat pesat dalam membawa berkah bagi kehidupan manusia. Namun, disamping manfaat yang telah disumbangkan, rupanya ilmu juga membawa kutukan yang berupa malapetaka, ditemukannya atom sebuah makhluk atau benda terkecil dalam susunan kehidupan kita yang juga bisa diambil manfaatnya dalam kehidupan kita bisa merusak struktur lapisan bumi dengan mudah, seperti adanya pemboman yang meresahkan seluruh jagat raya pada perang dunia 1l. Ditambah dengan hadirnya revolusi genetika, dimana manusia sebagai objek penelitian. Dengan penelitian genetika kita tidak bisa lagi menelaah organ-organ manusia dalam upaya untuk menciptakan teknologi yang memberikan kemudahan bagi kita, melainkan justru teknilogi ini telah mengubah manusia itu sendiri. Kiranya dapat kita deskripsikan, secara hakiki kenetralan ilmu telah mampu menyesuaikan dan memposisikan diri sesuai dan atau bagi kebutuhan umat manusia.

\section{KEBEBASAN NILAI DAN NILAI YANG TERBEBASKAN}

Selam ini, terdapat postulat yang menyatakan bahwa ilmu pengetahuan, baik ilmu alam maupun ilmu sosial haruslah objektif dan bebas nilai. Kedua-duanya haruslah berada dalam koridor akademis dan ilmiah tanpa terkontaminasi oleh aspek eksternal maupun internal yang menungganginya. Ternyata, postulat yang semacam ini telah muncul jauh sebelum kelahiran kita. Yaitu, kira-kira pada tahun 1909 dan 1914 yang dimotori oleh beberapa intelektual Eropa. Tokoh yang terkenal pada saat itu adalah Max Weber yang menuntut agar ilmu-ilmu sosial bekerja dengan bebas nilai, tetap juga relevan terhadap masalah nilai. Sedangkan tokoh yang melakukan perlawanan, perselisihan dan penolakan terhadap kebebasan nilai ilmu pengetahuan adalah Adorno dan Habermas yang lebih dikenal dengan "perselisihan positivisme." Istilah ini digunakan karena para wakil teori kritis masyarakat berpendapat bahwa tuntutan agar ilmu-ilmu sosial bekerja bebas dari berbagai penilaian, pada dasarnya berakar dalam pendekatan positivistik. Positivisme memang mau membatasi ilmu-ilmu pengetahuan pada fakta dan mengesampingkan pertanyaan-pertanyaan mengenai nilai sebagai irasional. 
Rasionalisme kritis sendiri menolak usaha Adorno dkk. untuk memasukkannya kedalam satu keranjang dengan positivisme, dan menyatakan diri sebagai anti posotivistik.

Dari perselisihan ini, akhirnya Habermas mengembalikan ilmu pengetahuan pada pengarahan penelitian oleh kepentingan-kepentingan vital manusia (yang berbeda untuk ilmu-ilmu alam dan ilmu-ilmu sosial). Maka menurut Habermas, bukan saja postulat kebebasan nilai merupakan ilusi bagi ilmu-ilmu sosial, melainkan juga bagi ilmu pengetahuan alam yang sama saja tidak bebas nilai.

Hal ini merupakan salah satu unsur teori kritis yang menuduh bahwa di belakang selubung objektivitas (kebebasan nilai) ilmu-ilmu, tersembunyi kepentingankepentingan kekuasaan.kepentingan-kepentingan itu dipahami sebagai ekonomis, sebagai kepentingan eksploitatif.

Hubungan antara ilmu pengetahuan dan kepentingan-kepentingan yang tidak bebas nilai ini menjadi salah satu usaha pokok Habermas. Dia menegaskan bahwa ilmu pengetahuan malah mungkin hanya sebagai perwujudan kebutuhan manusia yang terungkap dalam suatu kepentingan fundamental. Sebab itulah, maka Habermas berusaha memetakan tiga macam ilmu pengetahuan, masing-masing dengan lingkungan kepentingan, objek dan cirinya yang khas.

Kelompok ilmu pengetahuan pertama adalah ilmu-ilmu empiris analitis, seperti misalya imu-ilmu alam. Ilmu-ilmu ini mencari hukum-hukum yang pasti sehingga manusia, dengan menyesuaikan diri pada hukum-hukum itu, dapat memanfaatkan alam demi kebutuhannya. Tujuan ilmu-ilmu itu adalah penguasaan alam. Habermas menunjuk bahwa apa yang biasanya dianggap sebagai pengamatan-pengamatan inderawi dasariah bukanlah sebuah pengamatan, melainkan pengorganisasian kesan-kesan inderawi di bawah kepentingan-kepentingan penggunaan teknis proses-proses yang diobjektifkan.

Kelompok kedua adalah ilmu-ilmu historis hermeneutis, seperti ilmu sejarah, ilmu penelitian arti-arti tulisan dan dokumen sejarah lain. Ilmu-ilmu ini membutuhkan suatu pemahaman. Lingkungannya adalah interaksi dan Bahasa. Tujuannya adalah penangkapan makna. Ilmu-ilmu ini mengorganisasikan objeknya di bawah kepentingan perluasan intersubjektivitas. Maksudnya, yang diusahakan adalah peningkatan saling pengertian dengan tujuan tindakan bersama.

Kelompok ketiga yang dikhususkan Habermas adalah ilmu-ilmu tindakan, jadi yang mau membantu manusi dalam bertindak bersama. Disini termasuk ilmu ekonomi, 
sosiologi dan politik, begitu pula ilmu-ilmu reflektif seperti kritik ideologi, psikoanalisa dan filsafat. Kepentingan internal ilmu-ilmu itu adalah pembebasan. Metode dasar ilmuilmu itu adalah refleksi kritis atas sejarah subjek manusiawi.

Alhasil ialah bahwa ilmu-ilmu ini bukan hanya tidak bebas nilai atau bebas kepentingan, melainkan juga sebaliknya, hanya dapat terbentuk dalam medium sebuah kepentingan. Hal ini juga tidak menutup diri dari ilmu-ilmu transcendental, yaitu ilmuilmu yang memiliki nuansa agama.

Sedangkan Sony Keraf dan Mikhael Dua dalam bukunya, berkenaan dengan kebebasan nilai dari ilmu pengetahuan ini mengemukakannya sebagai tuntutan yang ditujukan kepada ilmu pengetahuan agar ilmu pengetahuan tersebut bisa dikembangkan dengan tidak memperhatikan nilai-nilai di luar ilmu pengetahuan itu sendiri. Tuntutan dasarnya adalah agar ilmu pengetahuan dikembangkan hanya demi ilmu pengetahuan an sich, dan karena itu ilmu pengetahuan tidak boleh dikembangkan dengan didasarkan pada pertimbangan lain di luar ilmu pengetahuan.

Apa yang dikemukakan di atas memang masuk akal dan mendasar. Berusaha agar ilmu pengetahuan menjadi dirinya sendiri, otonom, tunduk kepada kaidah-kaidah ilmiah saja, dan tidak boleh tunduk kepada otoritas dan nilai lain di luar ilmu pengetahuan. Maka ilmu pengetahuan harus bebas nilai, netral, harus lepas dari nilai-nilai lain di luar ilmu pengetahuan. Tetapi pertanyaan yang relevan di sini adalah apakah ilmu pegetahuan mempunyai otonomi yang sedemikian mutlak sehingga lepas dari campur tangan pihak lain? Bagaimana jadinya kalau ilmu pengetahuan dikembangkan sedemikian otonom sehingga pada akhirnya tidak mempedulikan berbagai nilai di luar ilmu pengetahuan dan akhirnya merugikan manusia? Jika demikian, lalu apakah tujuan dari ilmu pengetahuan itu? Mengenai hal ini, Sony Keraf dan Mikhael Dua telah memetakan dua kemungkinan dari kecenderungan dasar dalam melihat tujuan ilmu pengetahuan. Pertama, kecenderungan puritan elitis, dan kedua, kecenderungan pragmatis. Kecenderungan puritan elitis beranggapan bahwa tujuan akhir dari ilmu pengetahuan adalah demi ilmu pengetahuan itu sendiri. Ilmu pengetahuan bertujuan untuk mencari dan menemukan penjelasan yang benar tentang segala sesuatu. Bagi mereka, kebenaran ilmiah dari penjelasan ini hanya dipertahankan demi kebenaran murni. Kebenaran ilmiah ini hanya untuk memuaskan rasa ingin tahu manusia. Maka ilmu pengetahuan bagi mereka dikembangkan hanya-sekali lagi-demi ilmu pengetahuan. 
Konsekwensi dari kecenderungan ini adalah bahwa ilmu pengetahuan menjadi bidang yang sangat elitis. Ilmu pengetahuan hanya dicapai dan digeluti oleh segelintir orang saja. Tidak semua orang bisa mencapainya.ilmu pengetahuan lalu menjadi sesuatu yang mewah, jauh dari kehidupan riil manusia.

Sedangkan kecenderungan pragmatis beranggapan bahwa ilmu pengetahuan dikembangkan demi mencari dan memperoleh penjelasan tentang berbagai persoalan alam semesta ini. Ilmu pengetahuan memang bertujuan untuk memperoleh kebenaran. Tetapi bagi mereka, ilmu pengetahuan tidak berhenti sampai di situ saja. Yang penting adalah bahwa ilmu pengetahuan berguna bagi manusia untuk memecahkan berbagai persoalan yang dihadapi dalam hidupnya. Jadi, ilmu pengetahuan bukan dikembangkan hanya demi ilmu pengetahuan semata, melainkan juga demi menjawab berbagai persoalan kehidupan manusia.

Menurut mereka, ilmu pengetahuan menjadi menarik justru karena ia bertujuan membantu manusia, yang tanpanya, ilmu pengetahuan tidak ada artinya sama sekali. Jadi, penjelasan dan kebenaran objektif dan bebas niai; ya! Tetapi kebenaran dan penjelasan itu memiliki arti karena ia berguna bagi kehidupan manusia. Yaitu membuat hidup manusia menjadi lebih baik, lebih menyenangkan, dan lebih bahagia karena dengan ilmu pengetahuan, manusia lebih mampu memahami banyak hal. Dan dengan demikian bisa mengatur hidupnya menjadi lebih baik, karena dengan ilmu pengetahuan, diharapkan manusia mampu memecahkan berbagai persoalan dalam hidupnya.

Bagi mereka, kelompok yang memiliki kecenderungan pragmatis, ilmu pengetahuan dirasakan betul sangat membantu manusia untuk mengembangkan dunia dan kehidupan yang lebih manusiawi, adil, Bahagia, sehat, dan menyenangkan. Ilmu pengetahuan betul-betul melayani kepentingan manusia dan bukan demi ilmu pengetahuan semata. Demikian pula, manusia bukan untuk ilmu pengetahuan, melainkan ilmu pengetahuan untuk manusia. Jadi, yang perlu ditekankan di sini adalah aspek utility dari ilmu pengetahuan, yaitu aspek kegunaan dan-dengan meminjam bahasa Habermas di atasdemi sebuah kepentingan.

Sardan yang menurut penulis bisa dikategorikan sebagai salah satu tokoh yang dapat mewakili ilmuwan muslim-berusaha mengukuhkan keberadaan ilmu pengetahuan sebagai sebuah ilmu yang tidak bebas nilai, atau dengan kata lain bahwa ilmu pengetahuan itu pada dasarnya subjektif dan selalu ditopang oleh berbagai kepentingan 
semu. Namun apakah kepentingan itu baik atau buruk, maka hal itu merupakan kajian dari etika.

Sekedar untuk menguatkan argumen di atas, penulis juga menyuguhkan keberadaan ilmu ditinjau dari segi agama, tepatnya agama islam. Ketika pertama kali al-Qur'an diturunkan, dengan tegas dia telah mengajarkan pada kita untuk membaca. Sepintas lalu sudah dapat dimengerti bahwa manusia haruslah bisa membaca sekaligus mempelajari dan memahami apa saja yang Allah Swt ciptakan untuk mereka dengan disiplin ilmu dan metodologi dari ranah kajian masing-masing. Begitu pula dengan hadis Rasulullah Saw, beliau telah bersabda: "Barang siapa yang menghendaki dunia maka carilah dengan ilmu. Barang siapa yang menghendaki akhirat maka carilah dengan ilmu, dan barang siapa yang menghendaki kedua-duanya maka carilah dengan ilmu."

Maksud dari kedua sumber ajaran islam ini dengan tegas mengatakan pada segenap umat manusia tentang eksistensi ilmu pengetahuan. Setidaknya, ilmu pengetahuandengan berbagai bentuk dan wujudnya yang beragam-merupakan sarana dan motivator bagi perwujudan kepentingan-kepentingan mereka.

\section{REALITAS DALAM AKTIVITAS KEISLAMAN}

Satu contoh adalah Tafsir. Apabila ditakar dengan timbangan Habermas adalah bagian dari ilm-ilmu historis hermeneutis. Seperti halnya ilmu sejarah, dalam tafsir terdapat asbab al-wurud. Seperti halnya ilmu penelitian arti-arti tulisan, dalam tafsir yang diteliti adalah arti dan makna yang dikandung oleh al-Qur'an. Ilmu-ilmu ini mau memahami dan ini adalah definisi dari tafsir dan ta'wil itu sendiri. Lingkungannya adalah interaksi dan bahasa -Arab-al-Qur'an. Tujuan dari tafsir ini adalah penangkapan makna, yaitu hasil penafsiran. Ilmu-ilmu ini mengorganisasikan objeknya di bawah kepentingan perluasan intersubjektivitas. Taruhlah al-Zamakhsyari dengan karya tafsirnya, al-Kasyaf, telah menafsirkan beberapa ayat al-Qur'an seperti Surat al-An'am ayat 103 dan Surat alQiyamah ayat 22-23 yang digolongkan pada ayat mutasyabihat, karena tidak sesuai dengan fahamnya. Tujuannya tidak lain adalah untuk memberi dukungan dan pembelaan pada aliran Mu'tazilah, sebuah aliran yang dianutnya. 


\section{PENUTUP}

Gamblanglah bagi kita, bahwa pada dasarnya ilmu sungguh fleksibel dan bias kepentingan. Sesuatu yang menuntun kita pada arah kebahagiaan dan tujuan yang sesungguhnya. Netralitas ilmu pengetahuan yang terpasung seperti ini jelas menepis adanya dikotomi dalam tubuh ilmu pengetahuan itu sendiri. Dengan kata lain bahwa ilmu pengetahuan pada dasarnya tidaklah bebas nilai dan selalu diiringi oleh berbagai kepentingan yang melatarinya. Dengan begitu, maka nilai dari ilmu pengetahuan akhirnya tergadaikan. 


\section{DAFTAR PUSTAKA}

Baqir, Haidar, dan Zainal Abidin, (1999). Filsafat Sains Islami: Kenyataan atau Khayalan? dalam Mahdi Gulsyani, Filsafat-Sains Menurut al-Qur'an, terj. Agus Effendi. Bandung: Mizan.

Darmodiharjo, Darji dan Sidharta, (1996). Penjabaran Nilai-nilai Pancasila dalam Sistem Hukum Indonesia. Jakarta: Raja Grafindo Persada.

Einstein, Albert, (1999). Hakikat Nilai dari Ilmu: Pesan Kepada Mahasiswa California Institute of Technology, dalam Jujun S Sumantri. Ilmu dalam perspektif. Jakarta: Obor.

Gallagher, Kenneth T., (1994). Epistemologi Filsafat Pengetahuan, saduran P. Hardono Hadi. Yogyakarta: Kanisius.

Gazalba, Sidi, (1990). Sistematika Filsafat. Jakarta: Bulan Bintang.

Hardiman, Fransisco Budi, (1990).Kritik Ideologi: Pertautan Pengetahuan dan Kepentingan. Yogyakarta: Kanisius.

Kattsoff, Louis O., (1996). Pengantar Filsafat, terj. Soejono Soemargono. Yogyakarta: Tiara Wacana.

Keraf, Sony, dan Mikhel Dua, (2001). Ilmu Pengetahuan: Sebuah Tinjauan Filosofis. Yogyakarta: Kanisius.

Lacey, AR, (1996). A Dictionary of Philosophy. New York: Routledge.

Meetham, AR, (ed.), (1969). Encyclopaedia of Linguistic Information and Control. Tokyo Japan: Pergamon Press.

Redaksi, Tim KBBI, (1997). Kamus Besar Indonesia. Jakarta: Balai Pustaka.

Sumantri, Jujun S., (1999). Tentang Hakikat Ilmu: Sebuah Pengantar Redaksi, dalam Jujun S Sumantri, Ilmu dalam perspektif. Jakarta: Obor.

Sumantri, Jujun S., (tt.) Filsafat Ilmu: Sebuah Pengantar Populer. Jakarta: Sinar Harapan.

Suseno, Franz Magnis, (1992). Filsafat Sebagai Ilmu Kritis. Yogyakarta: Kanisius. 